\title{
THE LEgAL AdVISER IN INTERNATIONAL ORgANIZATIONS: TECHNICIAN OR GUARDIAN?
}

\author{
TREASA DUNWORTH*
}

The participation of lawyers as legal advisers to international organizations is reviewed from a historical and political perspective, looking primarily at the United Nations and the League of Nations. An inquiry is made into the "accountability debate" of international organizations and the role that legal advisers play in this regard. The issue of whether lawyers act as technicians or guardians in the international arena is reviewed historically both through academic publications, and through the writings of lawyers who have acted as international legal advisers. The 2003 invasion of Iraq and subsequent treatment of prisoners in Guantanamo Bay and Abu Ghraib are analyzed with respect to the advice given to states by their international legal advisers.

\begin{abstract}
La participation d'avocats et de conseillers juridiques aux organisations internationales est examinée d'un point de vue historique et politique, surtout dans le cas des Nations Unies et de la Société des Nations. On fait une enquête sur le «débat de responsabilisation» des organisations internationales et le rôle des conseillers juridiques à cet égard. La question de savoir si les avocats agissent en techniciens ou gardiens de la scène internationale est étudiée sur le plan historique, à la fois, dans les publications universitaires et les écrits d'avocats ayant agi comme conseillers juridiques internationaux. L'invasion d'Iraq en 2003 et le traitement subséquent des prisonniers à Guantanamo Bay et Abu Ghraib sont analysés relativement aux conseils donnés aux États par leurs conseillers juridiques internationaux.
\end{abstract}

\section{TABLE OF CONTENTS}

I. InTRODUCTION . . . . . . . . . . . . . . . . . . . . . . . . . 869

II. THE ACCOUNTABILITY GAP IN

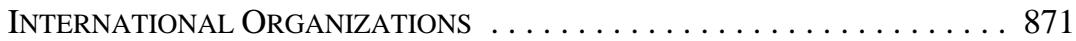

III. THE INTERNATIONAL SECRETARIAT AND THE LEGAL ADVISER . . . . . . 874

IV. Constitutional GUARdian OR TEChNician? ............. 877

V. INTERNATIONAL LAWYERS, IRAQ, AND THE WAR ON TERROR . . . . . . 882

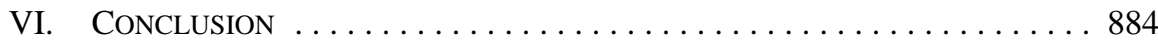

The first thing we do, let's kill all the lawyers. ${ }^{1}$

\section{INTRODUCTION}

Since the eighteenth century, lawyers have been active participants in the creation, defence, and development of individual rights and "have been among the main builders of

* $\quad$ Senior Lecturer, University of Auckland. Many thanks to Joanna Harrington and Craig Forcese for their work in organizing the 2nd ANZSIL Four Societies' Conference on International Law and Democratic Theory at the University of Alberta in September 2008, and to the participants for their comments and feedback. Thanks also to the anonymous reviewer for comments, to Rt. Hon. Sir Kenneth Keith for his assistance, and to Claire Nielsen for her excellent research assistance.

$1 \quad$ William Shakespeare, King Henry VI, Part 2, Act 4, Scene 2. Dick the Butcher's comment to Jack Cade is quoted to encapsulate the dilemma explored in this article — international lawyers as handmaidens to the establishment (in this case international organizations) or international lawyers as guardians of the law. Does the suggestion to kill all the lawyers reflect Dick's understanding of the important role lawyers play in maintaining the rule of law and thus, they should be the first targets in the revolution; or is it more properly explained on the basis that lawyers were seen as protecting a privileged and corrupt establishment and thus they ought to be the revolution's first casualties? Thanks to Christopher Penk on this point. 
the liberal state."2 The special responsibility of lawyers as "guardians of the rule of law" is a central theme in countless memoirs and biographies. Although there are fewer such accounts in international legal circles, the sensibility of the lawyer as guardian of the international legal order has had its constant champions. In the specific context of international organizations, however, there has been altogether less consideration of the role (guardian or otherwise) of the lawyer. ${ }^{3}$ This is a striking gap when one considers that questions about governance within international organizations are gaining momentum. The aim of this article, then, is to enquire into whether legal advisers should, or could, have a role to play in encouraging better governance within their organizations.

The inquiry stems from, and attempts to combine, two lines of analysis. The first is the socalled "accountability debate.” In the introduction to the collection of essays arising out of the First Four Societies Symposium, Professor José Alvarez reflected that, in liberal democracies at least, the "backlash against ever more intrusive forms of international law" has led to increasing questions as to the "accountability" or "transparency" of international legal obligations. ${ }^{4} \mathrm{~A}$ common feature of these questions is that they relate to the problem of the governance of international organizations, as noted in this symposium's call for papers. ${ }^{5}$ While I am unconvinced by the assertion that these concerns are new, ${ }^{6}$ or that they are the preserve of commentators within liberal democracies, ${ }^{7}$ it does seem that the question of governance of international organizations is gaining momentum.

The second line of analysis woven into the present inquiry is concerned with the role and function of the international lawyer within international organizations. Is the legal adviser a mere "housekeeper" or a facilitator for the policy organs, or might the adviser be more properly seen as a legal guardian of the institution? As will be seen, this question has been ever-present since the inception of the office of the legal adviser, articulated as a "perpetual dilemma” by Wilfred Jenks in the 1950s. ${ }^{8}$ With the increasing scope and influence of international organizations, the question is increasingly pertinent and deserves careful scrutiny. Despite this, in the literature examining the question of accountability for decisionmaking in international organizations, there has been little consideration given to the role of the lawyer in creating, fostering, or developing a culture of legality. Might exploring the role, function, and identity of legal advisers in international organizations be a way forward in

2 Lucien Karpik, “Political Lawyers” in Terence C. Halliday, Lucien Karpik \& Malcolm M. Feeley, eds., Fighting for Political Freedom (Oxford: Hart, 2007) 463 at 463-64.

3 With some notable exceptions, see Corell, infra note 77, Schachter, infra note 90; Jenks, infra note 8. José E. Alvarez, “Introducing the Themes” (2007) 38 V.U.W.L.R. 159 at 159.

See online: University of Alberta, Faculty of Law <http://www.law.ualberta.ca/docs/Call\%20for\%20 Papers.pdf>.

$6 \quad$ See e.g. Clyde Eagleton, “International Organization and the Law of Responsibility” (1950) 76 Rec. des Cours 323; Institute of International Law, Judicial Redress Against the Decisions of International Organs (19th Commission), 25 September 1957, reprinted in (1958) 52 A.J.I.L. 105; Felice Morgenstern, “Legality in International Organizations” (1976-77) 48 Brit. Y.B. Int’l L. 241; Ebere Osieke, “The Legal Validity of Ultra Vires Decisions of International Organizations” (1983) 77 A.J.I.L. 239.

$7 \quad$ B.S. Chimni, "International Institutions Today: An Imperial Global State in the Making” (2004) 15 E.J.I.L. 1.

$8 \quad$ C. Wilfred Jenks, “Craftsmanship in International Law” (1956) 50 A.J.I.L. 32 at 51. 
identifying possibilities to nurture a culture of legality within those organizations - of creating what Martti Koskenniemi has termed a constitutional mindset? ${ }^{9}$

With this overall question in mind, Part II provides an overview of the issue of accountability of international organizations generally, showing how Koskenniemi's call for a constitutional mindset offers a valuable way forward. Part III turns to the specific issue of the role of the legal adviser in international organizations and sets out the historical development of the international secretariat and in particular, the office of legal adviser within those secretariats. Part IV explores the various understandings over time of the role and function of a legal adviser - constitutional guardian or mere technician? In Part V, consideration is given to whether more recent developments, namely the "war on terror" and the 2003 invasion of Iraq and the role of lawyers therein might impact on those understandings. I conclude by suggesting that while there has always been some sense of a guardianship role for legal advisers within international organizations, there is a greater scope to develop a constitutional mindset.

\section{THE ACCOUNTABILITY GAP IN INTERNATIONAL ORGANIZATIONS}

It was not until the twentieth century that the entity we would recognize as an international organization today came into being with the League of Nations. ${ }^{10}$ Prior to that, international affairs had been conducted by means of public unions, associations, and the congress system of negotiations. ${ }^{11}$ Today, it is estimated that there are at least 232 such entities, probably 500 , and possibly as many as $700 .^{12}$ Their scope ranges from financial regulation to health, to security, to the environment. Given their growing numbers and ever-broadening scope, the increasing attention being paid to their power and influence is not surprising. ${ }^{13}$

Early writing on the powers of these organizations was relatively sparse, focusing on seminal developments in the United Nations, such as the Certain Expenses of the United Nations case, in which the International Court of Justice (ICJ) expressed the view that organs of the UN were presumed to have competence to act. ${ }^{14}$ There was some literature considering questions of legality, which arose in specific organizations. ${ }^{15}$ Overall, with some notable

Martti Koskenniemi, “Constitutionalism as Mindset: Reflections on Kantian Themes About International Law and Globalization” (2007) 8 Theor. Inq. L. 9.

10

David Kennedy, “The Move to Institutions” (1987) 8 Cardoza L. Rev. 841.

C.F. Amerasinghe, Principles of the Institutional Law of International Organizations, 2d ed. (Cambridge: Cambridge University Press, 2005).

Professor Amerasinghe calculates that there are in excess of 500 public international organizations in the world today (ibid. at 6, n. 10). Cf. José E. Alvarez, who suggests that there are around 300 organizations: "International Organizations: Then and Now" (2006) 100 A.J.I.L. 324 at 325-26, n. 9. For an overview, see Benedict Kingsbury et al., "Foreword: Global Governance as Administration National and Transnational Approaches to Global Administrative Law" (2005) 68:3 Law \& Contemp. Probs. 1. See also the symposium in (2006) 17 E.J.I.L. 1 at 1-278. In 2004, a journal dedicated to the study of the law of international organizations was launched: see Neils Blokker \& Ramses Wessel, "Introducing a New International Law Journal,” Editorial, (2004) 1 International Organizations Law Review 1.

14 Certain Expenses of the United Nations (Article 17, Paragraph 2, of the UN Charter), Advisory Opinion, [1962] I.C.J. Rep. 151.

15 See for example the work of Ebere Osieke on the International Civil Aviation Organization, including Ebere Osieke, "Unconstitutional Acts in International Organisations: The Law and Practice of the ICAO” (1979) 28 I.C.L.Q. 1, and on the International Labour Organization in "Ultra-Vires Acts in 
exceptions, the focus of the early "accountability debate" was on the Security Council's powers in the specific context of the reviewability of its actions by the ICJ. ${ }^{16}$

Over time, however, increasingly wide-ranging explorations have been taken, both in the sense of capturing international organizations generally, rather than just one organ of the UN, and in the sense that "accountability" might be achieved in ways other than by formal judicial review. Since 2002, the International Law Commission has been working on the topic of responsibility of international organizations under the guidance of Special Rapporteur Giorgio Gaja of Italy. ${ }^{17}$ Using the "Draft Declaration on Rights and Duties of States" ${ }^{18}$ as a template, the Commission has been working through the Special Rapporteur's reports and, so far, has adopted articles dealing with attribution of conduct, responsibility for the conduct of other entities, and circumstances precluding wrongfulness. ${ }^{19}$ Another arena for discussion has been the International Law Association, which examined the accountability of international organizations between 1998 and 2004. ${ }^{20}$ This study had a broader scope, attempting to capture the idea that there ought to be a means of achieving transparency in decision-making of political organs of international organizations with the ultimate aim of ensuring that those decisions are lawful.

Within the UN, the failure to prevent or respond in a timely fashion to the Rwandan genocide,$^{21}$ the fall of Srebrenica two years later, ${ }^{22}$ the corruption endemic in the Iraqi Oil for Food Programme, ${ }^{23}$ and concerns about alleged sexual misconduct by UN peacekeepers ${ }^{24}$ have all exerted pressure to address the so-called accountability gap. ${ }^{25}$ In the General

International Organizations — The Experience of the International Labour Organization” (1976-77) 48 Brit. Y.B. Int'l L. 259.

See e.g. W. Michael Reisman, “The Constitutional Crisis in the United Nations,” Notes and Comments, (1993) 87 A.J.I.L. 83; José E. Alvarez, "Judging the Security Council” (1996) 90 A.J.I.L. 1.

Report of the International Law Commission, Fifty-third session, UN GAOR, 56th Sess., Supp. No. 10, UN Doc. A/56/10 (2001) 370 at 370-77.

"Draft Declaration on the Rights and Duties of States" in Yearbook of the International Law Commission 1949 (New York: United Nations, 1956) at 286.

Michael J. Matheson, "The Fifty-Eighth Session of the International Law Commission," Current Developments, (2007) 101 A.J.I.L. 407 at 437-38.

International Law Association, Taipei Conference (1998): Committee on Accountability of International Organisations (First Report); International Law Association, London Conference (2000): Accountability of International Organisations (Second Report); International Law Association, New Delhi Conference (2002): Committee on Accountability of International Organisations (Third Report); International Law Association, Berlin Conference (2004): Accountability of International Organisations (Final Report). See also International Law Association, Accountability of International Organisations, Res. No. 19/2000 (London, 2000) and Accountability of International Organisations, Res. No. 1/2004 (Berlin, 2004). With the exception of the 1998 report, all are available online: International Law Association <www.ilahq.org/en/committees/index.cfm/cid/9>.

Report of the Independent Inquiry into the actions of the United Nations during the 1994 genocide in Rwanda, UN SCOR, 1999, UN Doc. S/1999/1257.

Report of the Secretary-General pursuant to General Assembly Resolution 53/35: The fall of Srebrenica, UN GAOR, 54th Sess., UN Doc. A/54/549 (1999).

See the reports by the Independent Inquiry Committee (IIC) into the United Nations Oil-for-Food Programme, online: IIC <http://www.iic-offp.org/documents.htm>.

24 Prince Zeid Ra'ad Zeid Al-Hussein, Special Advisor to the United Nations Secretary-General, A comprehensive strategy to eliminate future sexual exploitation and abuse in United Nations peacekeeping operations, UN GAOR, 59th Sess., UN Doc. A/59/710 (2005).

Jan Klabbers, “Kadi Justice at the Security Council?” (2007) 4 International Organizations Law Review 293 at $297-98$. 
Assembly's World Summit Outcome document, the issue of the need for greater transparency and accountability was stressed and reflected in strengthening a number of internal mechanisms. ${ }^{26}$ There are ongoing challenges to the Security Council's actions in designating persons or entities as terrorist through its committees. ${ }^{27}$ Questions of accountability of the Security Council have also arisen in the context of its administration in $\mathrm{Kosovo}^{28}$ and the impact of its resolutions on Iraq. ${ }^{29}$

Despite those pressures, a number of difficulties arise in attempting to discuss accountability. What, precisely, does it mean? How does it differ from responsibility? To whom, or what, should international organizations be accountable ${ }^{30}$ More general concerns are also voiced about calls for accountability. For example, Anne-Marie Slaughter has espoused the view that the real action takes place in transgovernmental networks and that to engage in reform of intergovernmental organizations is to miss the point. ${ }^{31}$ The International Law Association queried whether, in light of the fact that international organizations vary so much in terms of structure and function, it may be pointless to search for general principles. ${ }^{32}$ There are also questions as to whether the framework of state responsibility is appropriate to transplant onto international organizations and how to resolve the tension between member state responsibility and the responsibility of an international organization. ${ }^{33}$ And then, there are broader concerns relating to whether it is possible, or desirable, to attempt to transplant essentially domestic constitutional or rule of law ideals into the international system. ${ }^{34}$

Despite the absence of a clear way forward to explore the possibility or desirability of some form of constitutionality or responsibility, or without a clear understanding of what accountability might mean in the context of international governance, the problem remains that we are faced with powerful organizations with insufficient checks on that power or

World Summit Outcome, GA Res. 60/1, UN GAOR, 60th Sess., UN Doc. A/RES/60/1 (2005). Some of those are discussed in Klabbers, supra note 25.

Behrami v. France (2007), 45 E.H.R.R. SE10.

R. (on the application of Al-Jedda) v. Secretary of State for Defence [2007] UKHL 58, [2008] 1 A.C. 332 (exploring the question of whether and to what extent Security Council Resolution 1546 affects the otherwise applicable obligations of the United Kingdom regarding detainees in Iraq pursuant to the European Convention for the Protection of Human Rights and Fundamental Freedoms, 4 November 1950, U.K.T.S. 1953 No. 71, art. 5).

These and other questions are explored in Robert O. Keohane \& Joseph S. Nye, Jr., "Redefining Accountability for Global Governance" in Miles Kahler \& David A. Lake, eds., Governance in a Global Economy: Political Authority in Transition (Princeton: Princeton University Press, 2003) 386.

Anne-Marie Slaughter, “The Real New World Order” (1997) 76 Foreign Affairs 183 at 184-86.

Supra note 20.

Ralph Wilde, "Enhancing Accountability at the International Level: The Tension Between International Organization and Member State Responsibility and the Underlying Issues at Stake” (2006) 12 ILSA J. Int'l \& Comp. L. 395.

For discussion see Jan Klabbers, "Checks and Balances in the Law of International Organizations” in Mortimer Sellers, ed., Autonomy in the Law (Dordrecht: Springer, 2007) 141; Jan Klabbers, "Constitutionalism Lite" (2004) 1 International Organizations Law Review 31 at 50-51; John Ferejohn, “Accountability in a Global Context,” International Law and Justice Working Paper 2007/5 (Global Administrative Law Series), online: Institute for International Law and Justice (IILJ) <http://iilj.org/ publications/documents/2007-5.GAL.Ferejohn.web.pdf>. 
transparency as to its exercise. ${ }^{35}$ Writing about constitutionalism more broadly in international law (not simply in the context of international organizations), Koskenniemi explores what he terms "constitutionalism as mindset." 36 By this he means the idea that jurists, far from being mere technical implementers of the law, are in fact the law's nucleus. Constitutionalism understood as an architecture is an impoverished idea and, drawing on Immanuel Kant's idea of “moral politicans,” Koskenniemi calls for a broader understanding of constitutionalism - a better sensibility about how to act in a political world. ${ }^{37}$

This idea of the power (and indeed, responsibility) of the individual resonates with the work of Professor Antony Anghie, who observes that, as international lawyers, we are not neutral observers of international relations, but rather the architects of the law and the system we inhabit, and thus responsible for it. In the context of exploring sovereignty as an imperial construct, he says: "Lastly, and, perhaps, not entirely insignificantly, then, there is the international lawyer. Sovereignty doctrine, after all, does not exist independently of the scholars, the jurists and the practitioners who give it a particular content by arguing in particular modes and deciding what claims should be admitted and which rejected."38

Is it possible that the seeds of constitutionalism in international organizations might be contained within the international lawyers working within those organizations? A survey of the literature shows that while the language of accountability and constitutionalism might not be used, there is a long tradition of presenting the legal adviser in this light. It is to that aspect that we now turn.

\section{THE INTERNATIONAL SECRETARIAT AND THE LEGAL ADVISER}

The institution of the international secretariat was born with the League of Nations, and with it came the office of the legal adviser. ${ }^{39}$ Prior to this, international affairs had generally been conducted by means of the congress system with rapporteurs and secretaries, all of whom where national civil servants, serving the congresses on an ad hoc basis. ${ }^{40}$ They were in no sense "international civil servants" — simply ad hoc appointments from their national ministries, tasked with the administration of a particular congress.

Treasa Dunworth, "Towards a Culture of Legality in International Organizations: The Case of the OPCW” (2008) 5 International Organizations Law Review 119 at 139. For a series of case studies demonstrating the extent of the problem, see Sabino Cassese et al., eds., Global Administrative Law: Cases, Materials, Issues, 2d ed. (New York: Institute for International Law and Justice, 2008), online: IILJ <http://www.iilj.org/GAL/documents/GALCasebook2008.pdf>.

$36 \quad$ Koskenniemi, supra note 9.

37 Ibid.

38 Antony Anghie, Imperialism, Sovereignty and the Making of International Law (New York: Cambridge University Press, 2005) at 320.

$39 \quad$ See Jacques Lemoine, The International Civil Servant: An Endangered Species (The Hague: Kluwer Law International, 1995), which provides a thorough overview of the birth of the international secretariat, with its germination in the congress system prior to the League of Nations and International Labour Organization.

$40 \quad$ Ibid. at 16-18. 
The League was a complete departure from this system, in that there was to be a permanent international Secretariat. ${ }^{41}$ Although the Treaty of Peace between the Allied and Associated Powers and Germany ${ }^{42}$ itself provided for the Secretariat, to be headed by a Secretary-General, ${ }^{43}$ there was no direction in the Treaty of Versailles as to the Secretariat's structure or function and no mention at all of a legal adviser. The Secretariat was duly created and developed; with a total staff in excess of $600 .^{44}$

As with the League, the Charter of the United Nations provided for a Secretariat. ${ }^{45}$ However, while the Treaty of Versailles sets out the Secretariat in an apparently subordinate role to the Assembly and the Council of the League, the Charter created the Secretariat as a "principal organ" of the UN. ${ }^{46}$ Further, Part XV of the Charter (arts. 97-101) elaborates in much more detail the role and function of the Secretariat and the Secretary-General.

In both the League and the UN, there was a clear understanding that Secretariat staff should pledge loyalty to their respective organization. In June 1920, A.J. Balfour, the then British Representative to the League, noting that the Secretary-General had been given the authority to develop the Secretariat, reported to the Assembly on the Secretariat's "constitution." ${ }^{47}$ He stated that: "I emphasise the word 'International' because the members of the Secretariat once appointed are no longer the servants of the country of which they are citizens, but become for the time being the servants only of the League of Nations. Their duties are not national but international."48

Proposing that a resolution be adopted on the independence of the Secretariat, he stated:

I shall propose that no member of the Secretariat, during his or her term of office, shall accept any honour or decoration except for services rendered prior to the appointment. The reasons for this proposal are fairly clear; they commend themselves, I know, to my colleagues, and I hope they will commend themselves to the public. The members of the staff carry out, as I have explained, not national but international duties. Nothing should be done to weaken the sense of their international allegiance; the acceptance of special marks of

See Alfred Zimmern, The League of Nations and the Rule of Law, 1918-1935 (London: MacMillan, 1936) at 467.

28 June 1919, U.K.T.S. 1919 No. 4, art. 6 [Treaty of Versailles].

Hon. Sir James Eric Drummond, mentioned by name in an Annex to the Treaty of Versailles.

The 1936 budget allowed for a staff of 646. In 1931, it had been 699: see Alfred Zimmern, supra note 41 at 468.

Charter of the United Nations, 26 June 1945, Can. T.S. 1945 No. 7, art. 7(1) [Charter] (establishes the Secretariat); see also arts. 97-101. The Secretary-General, appointed by the General Assembly on the recommendation of the Security Council, is the chief administrative officer of the organization (art. 97). Article 2 of the Treaty of Versailles, supra note 42, provides for "an Assembly and ... a Council, with a permanent Secretariat" whereas art. 7(1) of the Charter establishes as "the principal organs of the United Nations”: a General Assembly, a Security Council, an Economic and Social Council, a Trusteeship Council, an International Court of Justice, and a Secretariat: see Bruno Simma et al., eds., The Charter of the United Nations: A Commentary (New York: Oxford University Press, 2002).

Report presented by the British Representative, Mr. A.J. Balfour, "Staff of the Secretariat” (1920) 1 League of Nations Official Journal 136.

Ibid. at 137. See for discussion by S.M. Schwebel, "The International Character of the Secretariat of the United Nations” (1953) 30 Brit. Y.B. Int'l L. 71 at 72. Schwebel goes on to discuss in detail situations in both the League and the UN where the international character of Secretariat staff has been challenged or compromised. 
distinction or favour, either from their own or from any other country, militates in our view against the general spirit of the Covenant. ${ }^{49}$

In the case of the UN, the need for independence and impartiality is formally reflected in the Charter. ${ }^{50}$ Article 100 provides:

1. In the performance of their duties the Secretary-General and the staff shall not seek or receive instructions from any government or from any other authority external to the Organization. They shall refrain from any action which might reflect on their position as international officials responsible only to the Organization.

2. Each Member of the United Nations undertakes to respect the exclusively international character of the responsibilities of the Secretary-General and the staff and not to seek to influence them in the discharge of their responsibilities. ${ }^{51}$

Both the League and UN's Secretariats have always had a Legal Office. Sir James Eric Drummond established a Legal Adviser Bureau as part of the League Secretariat and, at its First Session, the UN General Assembly resolved that one of eight principal units of the Secretariat was to be a "Legal Department." 52 The function of the Legal Department was to advise

the Secretariat and other organs of the United Nations on legal and constitutional questions; [assist] in the negotiation of agreements and other international instruments; [encourage] the progressive development of international law and its codification; [register] and [publish] treaties and international agreements and [maintain] liaison with the International Court of Justice. ${ }^{53}$

The Assistant Secretary-General in Charge of Legal Affairs was noted in the first Yearbook of the United Nations as "Chief Legal Adviser to the United Nations and the General Counsel of the United Nations." "S4 Since its formation, the function and structure of the Office has remained relatively constant. ${ }^{55}$ Today, there are approximately 160 staff members in the Office of the Legal Adviser, and its budget is US\$36 million biannually. Its structure has been replicated in most international organizations.

The UN Legal Adviser is, of course, a staff member of the Secretariat, and the foregoing survey reveals that the question of the role of the legal adviser is in many ways a broader question about the role of the international civil servant. In the context of examining the possible role of legal adviser in promoting or advancing a culture of legality or accountability, however, the question becomes whether the adviser has some special status

Balfour, supra note 47 at 138-39.

This was a clear concern in the negotiations: see Theodor Meron, The United Nations Secretariat: The rules and the practice (Lexington, Mass.: Lexington Books, 1977) at 1-7.

Charter, supra note 45, art. 100. The UN Staff Regulations, UN Doc. ST/SGB/2003/5 (2003), reinforce this independent role.

“Administrative Organization of the Secretariat” (UN Doc. A/RES/13(I)) in Yearbook of the United Nations 1946-47 (New York: United Nations, 1947) at 614.

Ibid. at 630-31.

Ibid. at 631.

See Simma et al., supra note 46 for an overview of the various restructuring that has taken place. 
within the organization — some special relevance as a "guardian" of the organization? ${ }^{56} \mathrm{How}$ are those advisers seen? How do they see themselves? Are they merely technicians within their organizations or might they also be constitution builders?

\section{CONSTITUTIONAL GUARDiAn OR TECHNiCIAN?}

Although often not formulated in such explicit terms, in the early years of the UN there were some important explorations of the role of the legal adviser. In 1948, then a senior legal counsellor in the UN Legal Department, Oscar Schachter published an article exploring the development of law through the legal opinions of the UN Secretariat. ${ }^{57}$ While many of the examples he explores are concerned with the actions of UN member states, he also explores a number of issues that touch on the legal powers of the organization itself. Of particular interest in the present context is his consideration of whether the Secretary-General had the power to unilaterally table a legal opinion for the Security Council's consideration during a debate on the continuing presence of Soviet troops in Iran. After consideration, and on the basis of its rules of procedure, the Council recognized that the Secretary-General could make statements to the Council regarding any matter under consideration. From this example, Schachter concludes that: "The competence of the Secretariat to furnish legal advice, even in connexion with the controversial political issues before the Security Council, was thus confirmed early in 1946." 58

The right of the Secretariat (and thus the adviser) to table an opinion was again questioned in 1947 during discussions of Indian partition and discussed in detail by the Sixth Committee. Schachter concludes that the position that it was necessary and proper for the Secretariat to do so was "tacitly adopted by the Committee since in its report it raised no question." ${ }^{59}$ Using these and other examples, Schachter paints a picture of the Legal Department playing an important and decisive role in the development of law and practice, including the constitutional question of the general powers of the organization. In his view, the legal adviser was not simply a handmaiden of the policy-making organs, but rather was an active participant in creating the legal order of the UN. Although he did not consider the question, it would seem that Schachter would have been open to the notion of the legal adviser as constitutional guardian and therefore part of the accountability framework.

The view from outside the organization was somewhat different. Writing four years after Schachter, in 1952, Gerald Fitzmaurice, then second legal adviser in the British Foreign Office, ${ }^{60}$ asked the question "how far does the organisation actually use the legal organs it possesses, and for what sort of purposes?" ${ }^{11}$ Examining three contemporary debates — the representation of China in the UN, the Anglo-Persian dispute, and the elections to the ICJ

Alfred Zimmern raises this question in the context of the League Secretariat as a whole: see supra note 41 at 460 .

$57 \quad$ Oscar Schachter, “The Development of International Law Through the Legal Opinions of the United Nations Secretariat” (1948) 25 Brit. Y.B. Int’l L. 91.

Ibid. at 94 .

Ibid. at 95.

Fitzmaurice would be appointed First Legal Adviser the following year. After almost three decades of government service, in 1960, he was elected to the International Court of Justice.

61 G.G. Fitzmaurice, "The United Nations and the Rule of Law" (1952) 38 Transactions of the Grotius Society 135 at 137. 
bench - he lamented the lack of recourse to the legal organs, ${ }^{62}$ and the favouring, as he saw it, of political expediency over the rule of law. ${ }^{63}$ Thus, in the view of Fitzmaurice, it would seem that while the Office of the Legal Adviser ought to have a prominent role within the Secretariat and the UN, generally, it did not.

In 1956, the then legal adviser to the International Labour Organization, Wilfred Jenks, considered the role of the legal adviser. ${ }^{64}$ What sets Jenks apart is that he explicitly articulates what he terms the "perpetual dilemma" of legal advisers - that is, the tension between the lawyer's role as technician and the lawyer's role as guardian. ${ }^{65}$ Noting the "housekeeping" duties of legal staff as well as the development of the particular branch of the law that the organization in question might be dealing with, he then turns to what he sees as the key role of the legal adviser: the general development of the law of international institutions and the drafting of law-making treaties. It is in these fields, he says, that

the legal staffs of international organizations have the opportunity, if they learn to combine vision and inventiveness with tact and judgment and acquire the practical wisdom which distinguishes instinctively between a time for boldness and a time for patience, to make a major contribution to the constructive development of the law at vital points. ${ }^{66}$

In exploring this idea, he notes the conservative approach of the lawyers in the context of the League of Nations. He is very clear that there is a constitutional practice of sorts emerging and is concerned that the legal practice of organizations should be more transparent. ${ }^{67}$

Thus, even in the first decade of the UN there are clearly differing visions of the role and function of the legal adviser, but leading contemporary commentators acknowledge the potential for some type of guardianship role within the legal counsel's office.

In the 1960s, the American Society of International Law took up the issue, sponsoring two conferences on the role of the legal adviser in 1963. The first dealt with national governments and their legal advisers in international dealings ${ }^{68}$ Schachter, by now Director of the General Legal Division of the UN, attended the conference and called for greater involvement of the legal adviser in the work of the organization. Even with, or perhaps because of, this call for activism, he clearly understood the need for the lawyer to be politically aware, expressing the view that the lawyer needs to be more mindful of the "complexity of the issues and the factual situations." ${ }^{69}$

62 Referring to the International Court of Justice, the Sixth Committee of the General Assembly, the International Law Commission, and the Department (as it was then) of the Legal Adviser.

Fitzmaurice, supra note 61 at 139-42.

Jenks, supra note 8 at 51 .

Ibid.

Ibid. at 50-51.

Ibid. at 47.

H.C.L. Merillat, ed., Legal Advisers and Foreign Affairs (Dobbs Ferry, New York: Oceana Publications, 1964).

69 "Legal Advisers and Political Proceedings in International Organs” (Summary of Remarks by Oscar Schachter at the Conference on Legal Advisers and Foreign Affairs, American Society of International Law, Princeton, 21 September 1963), ibid., 159 at 162. 
The second Society initiative focused entirely on legal advisers of international organizations - the first meeting of its kind. ${ }^{70}$ Held in August 1965 in the Rockefeller Foundation's Villa Serebelloni in Italy, the conference brought together official legal advisers to international organizations. ${ }^{71}$ Part One of the resulting collection is a thematically structured discussion of questions of international law that affect international organizations, including theories and practice concerning the powers and capacity of organizations, and decision-making procedures and internal administration. Part Two is a collection of descriptions of the structure and modes of operation of legal services in the organizations represented at the conference.

The "perpetual dilemma" set out by Jenks is apparent from the report. While the first set of chapters implicitly present the legal adviser as an active participant in the "constructive development of the law at vital points,"72 the accounts in the second part of the report, prepared by the legal advisers themselves, are far more technical and prosaic. Professor H.C.L. Merillat records the debate during the meeting about the nature of the role of the legal adviser. He says:

At several points questions were raised about what "law" the legal adviser applies. Presumably he is guided first of all by the terms of the constituent instrument setting up the organization. It was suggested that he also owes a special loyalty to the general principles of international law — perhaps even a loyalty and duty that override his duty to make his organization function effectively. ${ }^{73}$

However, he goes on to say that there was far from universal agreement among the participants with this suggestion. He continues, somewhat obscurely: "Others challenged this view and, while not trying to state any rule as to the hierarchy of norms, pointed out that on matters affecting the 'very life' of an organization the lawyer should seek for interpretations of the law of the organization that will promote its effective continuance."74

Even if the parameters of the debate are not altogether clear, it is clear that there were competing visions of what is the appropriate role of a legal adviser. Perhaps more significantly, the general tenor of the book — the fact of the meeting itself — suggests that there might be an emerging sense of what it is "to be a legal adviser" and this, in itself, suggests a shared endeavour towards the "rule of law."

Despite those promising early discussions on the role of the adviser, discussion seems to have subsequently stalled. By 1977, Professor Theodor Meron, in a call for urgent and fundamental reforms to address what he saw as the politicization of recruitment within the Secretariat, reflects on the decline of the role of law. ${ }^{75}$ Significantly, he notes the

H.C.L. Merillat, ed., Legal Advisers and International Organizations (Dobbs Ferry, New York: Oceana Publications, 1966).

71 Council of Europe, European Communities Councils and Executives, Inter-American Development Bank, International Atomic Energy Agency, International Bank for Reconstruction and Development, International Labour Office, International Monetary Fund, Organization of American States, and the United Nations.

72 Merillat, supra note 70 at $\mathrm{x}$.

Ibid. at 5.

Ibid.

Meron, supra note 50. 
marked decline in the number of requests for legal opinions from the Secretary-General and from various departments of the Secretariat, including the Office of Personnel Services. This may be another indication of the politicization of the Secretariat, of the diminishing role of law in the Organization, and of the increasing power of the various departments that want to be free to establish policy without submitting themselves to legal opinions. Indeed, it may well be that many salutary opinions of the Legal Counsel on questions such as clearance are rapidly becoming anachronistic. ${ }^{76}$

That may well have been the case in the 1970s, but in the last 20 years there has been a renewed interest in the role of the legal adviser. Initially at least, this was concerned mainly with the role of the national legal adviser in questions of foreign policy. Since 1990, legal advisers to ministries of foreign affairs have been meeting in New York, coinciding with the meetings of the Sixth Committee. ${ }^{77}$ There have also been various regional meetings of legal advisers. ${ }^{78}$ In 1999, the UN, as part of its mandate for the UN Decade of International Law, published a collection of essays by legal advisers examining the role of the legal adviser more broadly, including the role of the legal adviser in international organizations. ${ }^{79}$ Annual meetings are also now held for legal advisers within international organizations, or at least within the UN common system.

The dual role of the legal adviser, technician and guardian, permeates these discussions, as do the more informal writings on, or reflections by, legal advisers. ${ }^{80}$ There is no shortage of discussion, reporting, and analysis of technical issues. In particular, the reports from the meetings of the legal advisers tend to stress "housekeeping" matters, rather than question of constitutional guardianship. ${ }^{81}$ Although no reports are issued regarding the meetings of the legal advisers of international organizations, it seems that for the moment at least, the tenor of these meetings is technical, considering such matters as paternity provisions in the Staff Regulations. The emphasis on technical lawyering is also evident in the 1999 collection of essays. $^{82}$

However prevalent the pragmatism, there is an ever-present acknowledgement of the greater potential of the legal adviser. For example, this is evident in Koskenniemi's closing

Ibid. at 83.

See generally Hans Corell, “Cooperation among Legal Advisers on Public International Law” in United Nations, Collection of Essays by Legal Advisers of States, Legal Advisers of International Organizations and Practitioners in the Field of International Law (New York: United Nations, 1999) 97 at 98-103 [Corell, "Cooperation"]. Short accounts of the meetings can be found as follows: Hans Corell, "Legal Advisers Meet at UN Headquarters in New York" (1992) 85 A.J.I.L. 371; Hans Corell, "Second Legal Advisers' Meeting at UN Headquarters in New York” (1994) 61-62 Nordic J. Int'l L. 3; Hans Corell, “Third Legal Advisers' Meeting at UN Headquarters in New York” (1993) 87 A.J.I.L. 323; Barry Mawhinney \& Kim Girtel, "Fourth Legal Advisers’ Meeting at UN Headquarters in New York” (1994) 88 A.J.I.L. 379; Miguel Angel González Félix, "Fifth Legal Advisers' Meeting at UN Headquarters in New York" (1995) 89 A.J.I.L. 644; P. Sreenivasa Rao, "Sixth Meeting of Legal Advisers of the UN Member States” (1996) 36:4 Indian Journal of International Law 75; Lars Magnuson "Seventh Meeting of Legal Advisers of UN Member States” (1997) 66 Nordic J. Int’l L. 393. For example the Asian-African Legal Consultative Organization: see Corell, "Cooperation,” ibid. at 101. United Nations, supra note 77.

See e.g. Robbie Sabel, "The Role of the Legal Advisor in Diplomacy” (1997) 8 Diplomacy \& Statecraft 1.

This assessment is based on the short reports listed in supra note 77 .

United Nations, supra note 77. Although the contributions by Corell and Koskenniemi stand out in this regard. 
chapter in the 1999 publication. ${ }^{83}$ Generally, the guardianship potential in a legal adviser's role does not seem to be presented as a dilemma, but rather presented in such a way that the two roles - technical and constitutional — sit more comfortably with each other. When legal advisers themselves reflect on their role, both strands are evident and the dual function does not seem to present a conflict, but rather acts in tandem. ${ }^{84}$ For example, Richard W. Edwards, Jr., writing about the role of the general counsel in the international financial institutions, feels that the legal adviser is both a technician and also has responsibilities to the organization itself. ${ }^{85}$ He says, "the loyalty of the general counsel should be understood to run to the organization itself and to the law applicable to international organizations."

This idea that the dual function might be complementary, rather than posing a dilemma, is most evident in the reflections of Dr. Ralph Zacklin, retired from extensive service in the Office of Legal Affairs, who considered the role of the legal adviser in international organizations generally. ${ }^{87}$ In that discussion, there is a return to the more expansive vision of the role and a very explicit depiction of the legal adviser, not simply as a legal technician but also as some kind of guardian. Who is better placed, Zacklin asks, than the legal adviser to be the promoter and the guardian of the rule of law in the UN? ${ }^{88}$

He sees the technical parts of the role as feeding into that overarching vision:

[T] he work of the legal adviser in the day-to-day activities of the Organisation plays a significant role in the nurturing of international law. Each advice, opinion, memorandum or brief helps to creates a culture of respect for the law within the Organisation's Secretariat and among Member States, and the accumulation of such legal activity over the years has undoubtedly done much to enhance the place and role of international law in international relations. ${ }^{89}$

The foregoing survey reveals that there have always been two visions of the legal adviser in international organizations. The first involves a housekeeping or administrative function and in this respect, the legal advisers are in the same situation as the other international civil servants. The second, and more significant, vision is that of constitutional guardian of the organization, and this sets the legal adviser apart from other Secretariat staff. It is this latter role that contains the seeds of a constitutional mindset for lawyers within international organizations.

In the years since 2001, there has been unprecedented analysis of the role of law, and international lawyers, in the conduct of the "war on terror" and the decision to invade Iraq

Martti Koskenniemi, “Between Commitment and Cynicism: Outline for a Theory of International Law as Practice" in United Nations, ibid., 495.

Arguably, the absence of any external mechanism to check the actions of the organization in question means that an internal "rule of law" is even more important.

Richard W. Edwards, Jr., "The Role of the General Counsel of an International Financial Institution” (2008) 17 Kan. J.L. \& Pub. Pol’y 254.

Ibid. at 269.

Ralph Zacklin, "The Role of the International Lawyer in an International Organisation" in Chanaka Wickremasinghe, ed., The International Lawyer as Practitioner (London: British Institute of International and Comparative Law, 2000) 57.

Ibid. at 63-64.

Ibid. at 64 . 
in 2003. How, if at all, might that analysis inform any consideration of the role of the international lawyer within an international organization? It is to that question that we now turn.

\section{INTERNATIONAL LAWYERS, IRAQ, AND THE WAR ON TERROR}

In 1977, Schachter wrote about what he saw as an "invisible college of international lawyers." 90 There was, he said, a sense of community among international lawyers — with a shared endeavour of advancing international law, notwithstanding differences between the government and academic lawyer, nor the difficulties inherent in any suggestions about the objectivity of the law. If such a community of international lawyers did exist, it has been fundamentally challenged by the deeply divisive war on terror and the 2003 invasion of Iraq.

In terms of Iraq, academic international lawyers were vocal in both their opposition to, and support of, the 2003 invasion. ${ }^{91}$ Of particular interest in the present context, however, was the unprecedented attention paid to the advice given to governments by their legal advisers. In the United Kingdom, the advice of Lord Goldsmith, the Attorney General, to the Prime Minister regarding the legality of the planned military action against Iraq was publicly released. ${ }^{92}$ While this had been an attempt to justify the legality of the proposed invasion in answer to critics at home and abroad, it became counterproductive with the revelation that the advice had in fact been amended from its original conclusions. The original advice, dated 7 March had concluded that, in the absence of a more explicit Security Council resolution authorizing the use of force against Iraq, any military force would not be lawful under international law. ${ }^{93}$ Essentially, the Attorney General had abandoned his first opinion for the sake of political expediency. ${ }^{94}$ Similarly, in Australia, the advice from the legal adviser was released into the public domain and subjected to scrutiny and criticism by academic international lawyers. ${ }^{95}$

In regards to the war on terror, the focus of commentary regarding the role of legal advisers has been on their part in creating the permissive environment that ultimately led to the appalling abuses at Guantanamo Bay, Abu Ghraib, and other detention centers. ${ }^{96}$ Senior lawyers at the heart of the United States administration advised the policy-makers that the

Oscar Schachter, “The Invisible College of International Lawyers” (1978) 72 Nw. U.L. Rev. 217. By now, Schachter was retired from the United Nations and writing as a Professor at Columbia Law School. See e.g. the account by Matthew Craven et al., "We are Teachers of International Law" (2004) 17 Leiden J. Int'l L. 363. See also the summary of reactions set out by Hilary Charlesworth, "Saddam Hussein: My Part in His Downfall” (2005) 23 Wis. Int'l L.J. 127 at 137-39.

U.K., H.L., Hansard, vol. 646, col. WA2 (17 March 2003) (Lord Goldsmith, Attorney General). Both versions are reproduced in Philippe Sands, Lawless World: The whistle-blowing account of how Bush and Blair are taking the law into their own hands (London: Penguin Books, 2006) at 328-44.

See Rt. Hon. E.W. Thomas, “An indictment of Tony Blair, and the failure of the political process” in Ken Coales, ed., The Spokesman War Crimes (Nottingham, U.K.: Russell Press, 2007) 12; Sands, ibid.; Craven et al., supra note 91.

In Australia, see Attorney-General's Department and Department of Foreign Affairs and Trade, Memorandum of Advice on the Use of Force Against Iraq (2003), reprinted in (2003) 4 Melbourne Journal of International Law 178.

For a full account see Philippe Sands, Torture Team; Rumsfeld's Memo and the Betrayal of American Values (New York: Palgrave MacMillan, 2008). Cf. Jack Goldsmith, The Terror Presidency: Law and Judgment Inside the Bush Administration (New York: W.W. Norton, 2007). 
Third Geneva Convention ${ }^{97}$ did not apply to Al Qaeda or the Taliban, thus validating the administration's view that many international legal obligations could be avoided. ${ }^{98}$ Coupled with that, Jay Bybee, Assistant Attorney General, then provided the administration with a narrow definition of "torture" as only covering the most extreme acts, saying pain must be "of intensity akin to that which accompanies serious physical injury such as death or organ failure.”99

There is no doubt that international lawyers have gained a high profile in the course of these years; both positively in terms of standing up for international law and negatively in terms of being seen as the handmaidens to the policy-makers. It is also the case that the debates have fuelled what Hilary Charlesworth terms the "perennial anxieties" of international lawyers in that just as international law seemed more relevant than ever, it became irrelevant and ultimately disregarded by the policy-makers. ${ }^{100}$

Whatever the ultimate verdict, this latest generation of writing on the role of the international lawyer provides some illumination on the role of the legal adviser in an international organization. First of all, it highlights that the debate about the ability of the legal adviser in an international organization is really no different than the more general question about the law-policy debate. Writing in the context of the domestic legal adviser, Richard Bilder argues that while international law is only one among many factors in the foreign policy-making process, it is an important factor. Explaining why in his view it is important for the American government to have lawyers involved in foreign policy decisionmaking, he says: "Law must at least speak to power, even if power does not always choose to give it determinative weight.",101

The same dynamic lies at the heart of the question of the role of the legal adviser within an international organization. The problem of the loyalty of the domestic legal adviser (to his/her national interest or to the international rule of law) has long been recognized by commentators. ${ }^{102}$ The issue in the context of an international organization is really no different.

Geneva Convention Relative to the Treatment of Prisoners of War, 12 August 1949, 75 U.N.T.S. 135 (entered into force 21 October 1950).

Alberto R. Gonzales, "Decision Re Application of the Geneva Convention on Prisoners of War to the Conflict with Al Qaeda and the Taliban,” Memorandum for the President (draft) dated 25 January 2002, reprinted in Karen J. Greenberg \& Joshua L. Dratel, eds., The Torture Papers: The Road to Abu Ghraib (Cambridge: Cambridge University Press, 2005) 118.

Jay S. Bybee, "Standards of Conduct for Interrogation under 18 U.S.C. §§ 2340-2340A,” Memorandum for Alberto R. Gonzales, Counsel to the President, dated 1 August 2002, reprinted in Greenberg \& Dratel, ibid., 172 at 213-14.

Charlesworth, supra note 91 at 128.

Richard Bilder, "On Being an International Lawyer" (2006) 3 Loyola University of Chicago International Law Review 135 at 142 [emphasis in original]. Compare the statement of the United Kingdom's Prime Minister Eden during the Suez Canal crisis: "Fitz [Sir Gerald Fitzmaurice, the then Legal Adviser in the Foreign Office] is the last person I want consulted.... The lawyers are always against our doing anything. For God's sake, keep them out of it. This is a political affair," as discussed by K.J. Keith, "The World Community and its Laws" (2006) 22 N.Z.U.L. Rev. 1 at 4.

See e.g. Thomas M. Franck “An Outsider Looks at the Foreign Office Culture” (2005) 23 Wis. Int'l L.J. 1 and response by William D. Rogers “'Power' to 'Law': It’s Not as Bad as All That” (2005) 23 Wis. Int'l L.J. 39. 
The second point of illumination is that the debate surrounding the war on terror or the invasion of Iraq has, perhaps ironically, served to reveal a "college of international lawyers." As Matthew Craven and his colleagues reflected, those who had routinely critiqued international law worked to knock it "off its pedestal, and expose its darker dimensions," 103 were now defending international law, state sovereignty, and legal argument. ${ }^{104}$ Similarly, it may be that as challenges to international organizations continue, it will be lawyers who move to defend them - not by denying the role of law at all, but by making room for the rule of law.

\section{CONCLUSION}

It would seem then, that like his or her domestic counterpart, the legal adviser of an international organization is both a technician and contains the seeds of a constitutional mindset. The latter role has thus far been relatively neglected, although its champions have been constant. The work of Schachter has been important in this regard. Hans Corell, another long-standing legal adviser within the UN, worked actively to highlight the importance of the role of the legal adviser. Christopher Weeramantry has been a tireless champion for international lawyers to see themselves as "custodians" of the discipline. ${ }^{105}$ Most recently, in his keynote address at the 2008 Annual Meeting of the American Society of International Law, Prince Zeid Ra'ad Zeid Al-Hussein of Jordan explored the responsibilities of international lawyers in pursuing international justice. ${ }^{106}$

Charlesworth is no doubt correct when she reflects that the recent challenges to international law have punctured "the myth of the reasoned effectiveness of international lawyers." 107 She says: "The tactful, urbane and influential figure of the international legal adviser described by Richard Bilder and Hans Corell is not recognizable in this context and Oscar Schachter's conscience juridique seems to be have been completely corrupted."108

That may be so, but it remains the case that, in the context of seeking greater accountability and better governance of international organizations, the concept of developing a "constitutional mindset" within legal advisers to international organizations today may offer us the best chance of speaking law to power.

Craven et al., supra note 91 at 366.

Ibid.

C.G. Weeramantry, Universalising International Law (Leiden: Martinus Nijhoff, 2004) at 211.

Prince Zeid Ra’ad Zeid Al-Hussein, "For Love of Country or International Criminal Law” (Keynote Address, American Society of International Law, Washington, D.C., April 2008).

Charlesworth, supra note 91 at 141.

Ibid. at 139 [emphasis added]. 